\title{
Mudanças na narrativa juvenil portuguesa depois de 1974
}

Francesca Blockeel

Lessius Hogeschool (Bélgica)

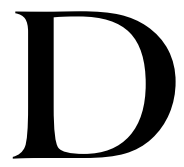

epois da Revolução dos Cravos, a literatura juvenil conheceu em Portugal uma enorme evolução, tanto que se fala com razão de um boom, e talvez até se justifique falar também neste caso de uma verdadeira revolução. Efectivamente, este sector do panorama editorial, que dantes ocupava um lugar de segundo plano, torna-se o mais explosivo terreno da produção escrita no Portugal da década de 80. Por isso pareceu-nos de particular interesse analisar as mudanças mais importantes desta produção.

O 25 de Abril foi a alavanca que conduziu Portugal no domínio da literatura infanto-juvenil a uma orientação paralela à do resto da Europa, num processo que conheceu três momentos. De facto, a evolução e a renovação tardaram uns cinco anos antes de se fazerem notar. Os primeiros anos a seguir à Revolução foram bastante caóticos, e as paixões entre conservadores e progressistas avivaram-se perigosamente. Essas paixões e o digerir da própria Revolução tinham repercussão até nas narrativas que se escreveram para crianças. Apareceram vários curtos livros panfletários que pretendiam denunciar as desigualdades sociais, defender um modelo de sociedade socialista ou convencer os leitores de uma causa. Outras tinham um claro teor didáctico, porque queriam divulgar determinados conhecimentos (por exemplo, a vantagem de saber ler e escrever) ou clarificar conceitos políticos como, por exemplo, a relação entre explorados e exploradores. As narrativas não tinham grande pretensão literária, mas antes ideológica, e por conseguinte possuíam um valor literário limitado, razão pela qual a maioria destes livrinhos depressa desapareceu do palco. Porém, um deles ainda está à venda hoje em dia: Catarina de Todos Nós, de Sidónio Muralha, escritor principalmente para adultos e poeta para crianças, que viveu muito tempo no Brasil. 
Depois desse período, a paixão política amainou e houve mais tempo para uma reflexão matizada: é nos finais dos anos 70 que nasce uma produção literária para crianças e jovens liberta de uma ideologia restritiva e aberta às correntes modernas, "numa procura de recuperação de reconhecido atraso". ${ }^{1}$ A época que se segue vai ser marcada por uma grande riqueza e variedade na literatura para os jovens. Nos anos 90, porém, o movimento parece de certa maneira ter perdido o fôlego. O número de escritores escasseia e escreve-se nitidamente menos obras de qualidade.

O processo a partir do boom da literatura juvenil vai ser analisado neste trabalho a partir de três ângulos: as mudanças no público-alvo, a evolução e as tendências que se podem constatar no género de livros e na temática abordada.

\section{0 público-alvo}

Num trabalho de 1973 apresentado aquando da "Exposição de Livros Juvenis" organizado pelo Ministério da Educação Nacional em Lisboa, João David Pinto-Correia dá um apanhado de A Literatura Juvenil em Portugal. Nele observa que são quase inexistentes os estudos sobre a literatura para os jovens de mais de dez anos, sejam de carácter histórico, de temática ou de apreciação da obra de um escritor português, por ser "uma literatura que quase não existe" em Portugal. ${ }^{2}$ Se a obra de Odette de Saint-Maurice constitui neste aspecto uma excepção, dirigindo-se explicitamente a adolescentes, é um facto incontestável que, regra geral, as poucas narrativas juvenis escritas nas décadas antes de 74 eram desinteressantes, não falavam da realidade e apresentavam crianças que não eram de carne e osso. Esta carência de livros juvenis tem muito a ver com a maneira como se encarava a leitura dos jovens: ${ }^{3}$

As lendas, os romances tradicionais, as fábulas, as canções de gesta, os bestiários medievais, as hagiografias, os poemas épicos, etc., não contam com características que os tornam desde logo aceitáveis pelos jovens? A Ilíada não será um romance de aventuras? E a Odisseia e a

${ }^{1}$ ROCHA, 1984, p.103.

${ }^{2}$ PINTO-CORREIA, 1973, p.14.

3 PINTO-CORREIA, 1973, p.26. 
Eneida, livros de viagens? Na nossa literatura, as novelas do ciclo bretão, o Amadis, o Palmeirim e outras obras-primas não se imporão aos jovens pelas aventuras que relatam e, quanto à técnica literária, pelo predomínio da intriga, das peripécias e até do próprio suspense? [Mencionam-se os relatos dos navegadores portugueses, crónicas sobre o Novo Mundo, a Peregrinação e Os Lusíadas.] Abeirando-nos assim da literatura juvenil, diríamos que a nossa talvez atinja um dos mais ricos níveis do Mundo.

Ora, essa era mais ou menos a ideia geral entre a maioria das pessoas que se ocupavam da leitura dos jovens até aos anos 80, a saber que a partir dos 13 anos a leitura de obras clássicas (Herculano, Garrett, Fernão Mendes Pinto, Fernão Lopes...) podia aproveitar aos jovens: bastavam-lhes os livros romanceados da História de Portugal, das aventuras marítimas, e adaptações da literatura clássica. Já desde os últimos anos do ensino básico se preparavam as crianças para essa orientação, o que se evidencia ao folhear os manuais de aprendizagem da gramática e da língua portuguesa, que na sua maioria recorriam quase sistematicamente a trechos da literatura clássica para adultos e quase nunca aos textos escritos para crianças ou jovens. De maneira nenhuma foi sentida a necessidade de escrever livros de certa extensão especificamente para essa faixa etária.

Será exactamente no domínio das narrativas para pré-adolescentes e adolescentes que a mudança e a pujança da literatura portuguesa pós-revolucionária mais se fazem sentir. A partir do fim dos anos 70 é que se começa a escrever romances atraentes de aventuras e narrativas sobre experiências e vivências dos jovens com os amigos, os pais, a vida escolar, etc, narrativas que conseguem captar a atenção dos leitores, em vez das colecções tradicionais de contos que, regra geral, não ultrapassavam as cinquenta páginas. O público-alvo é que mudou por completo no panorama da literatura infanto-juvenil portuguesa. Ao público de crianças dos primeiros anos do Ensino Básico, digamos até aos dez anos, vem acrescentar-se o dos pré-adolescentes, os alunos do ensino preparatório, miúdos entre os 10 e os 13 anos, sem grande gosto pela leitura, a quem os livros para crianças já não dizem nada e que ainda não conseguem entrar nas obras dos mais crescidos. É uma idade difícil em que até os que têm gosto pela leitura o podem perder.

Até os anos 90 também se podia constatar uma carência de livros para outra faixa etária, a dos adolescentes: não existia quase nada que fosse 
escrito para os jovens maiores de 14 anos. No entanto, na literatura anglo-saxónica e da Europa Ocidental já se fala há algum tempo de uma literatura "para os quase adultos", a Young adult fiction: "Previously children would have been expected to graduate to serious adult literature via Sir Walter Scott or Dickens. There was a gap in the market, it was perceived, for readers too old for children's stories and not yet ready for adult literature». ${ }^{4}$ Como diz Maria Nikolajeva: "The Young adult novel (or teenage novel, or adolescent novel) depicts the characters' marginal situation between childhood and adulthood, when there is no way back, but the inevitability of the final step into grown-up life has not yet been accepted.${ }^{5}$ Esta investigadora explica que a diferença em relação às muitas outras narrativas juvenis que também retratam o processo de maturação de um herói reside no facto de este tipo de livros se caracterizar pela marginalidade, a hesitação e às vezes a impossibilidade de dar o passo decisivo.

A escritora Alice Vieira observou numa entrevista que em Portugal não se distingue entre literatura infanto-juvenil e "Young adult fiction" ("O dia dos pequenos leitores" in: Público 2/4/1994). No entanto, alguns dos seus livros apresentam de certo modo várias facetas dessa orientação, como Úrsula a Maior (1989), Os Olhos da Ana Marta (1990) e Se Perguntarem por Mim Digam que Voei (1996). Contudo, é em 1994 que aparecem narrativas que correspondem em quase todos os traços característicos a este género: Diário de Sofia aos 15 anos (1994), de Luísa Ducla Soares, e sobretudo $A$ Lua de Joana (1994), de Maria Teresa Maia Gonzalez. Este livro, que aborda os temas da droga, do sexo e da morte, conheceu um êxito enorme. Talvez devido a esse sucesso, a escritora iniciou em 1996, na editora Difel, uma colecção para esta faixa etária, "Profissão: Adolescente", que já conta uma quinzena de volumes. Ana Maria Magalhães e Isabel Alçada, que formam uma dupla de escritoras, também enveredaram por este caminho com Diário Secreto de Camila (1999) e Diário Cruzado de João e Joana (2000).

Pode-se dizer que os escritores, sem no entanto esquecerem os mais novos, se dirigiram nos anos 80 sobretudo aos pré-adolescentes, e na

\footnotetext{
${ }^{4}$ KNOWLES \& MALMKJÆR, 1996, p.28.

${ }_{5}^{5}$ NIKOLAJEVA, 1996, p.16.
} 
década de 90 também aos adolescentes e "young adults", o que antes de 1974 quase não acontecera. A essa manifesta mudança no público-alvo está estreitamente ligada uma ampliação dos géneros praticados.

\section{Os géneros}

Como nos cingimos neste trabalho sobretudo à literatura para jovens, deixamos de lado toda a literatura destinada aos mais novos, como os livros só de imagens, os picture books, e para os leitores que se iniciam na leitura.

\subsection{A poesia}

Embora José António Gomes ${ }^{6}$ lamente a pobreza do panorama editorial neste domínio, a produção poética nos vinte e cinco anos depois do 25 de Abril não é tão escassa. De facto, como também é característico da literatura portuguesa para adultos, a parte ocupada pela poesia é considerável na literatura infanto-juvenil. O próprio Gomes, no seu ensaio A Poesia na Literatura para a Infância, ${ }^{7}$ dá uma bibliografia de obras poéticas e antologias de poesia: dos 156 títulos, 104 são escritos depois de 1974, o que equivale a 66\%. O autor não incluiu nesta lista a obra de Matilde Rosa Araújo, porque forneceu uma bibliografia separada das 27 obras de contos e poemas desta escritora, publicados até 1993. Os mais prolíficos poetas contemporâneos para crianças, além de Matilde, são José Jorge Letria, Maria Alberta Menéres, Leonel Neves, Luísa Ducla Soares, e ultimamente têm surgido mais alguns poetas para os novos, como Violeta Figueiredo, Vergílio Alberto Vieira e João Pedro Mésseder. É de referir que para os mais crescidos se escreve muito menos poesia, o que é, aliás, um fenómeno geral nas outras literaturas. Pelo menos sete antologias viram a luz a partir de 1974: de Alice Gomes há Poesia para a Infância (1974), de Catarina Ferreira Brincar Tambémé Poesia (1980), de Fernando Camacho Palavras de Cristal (1983), de Natércia Rocha Verso Aqui... Verso Acolá(1990), de Sophia de Mello Breyner Andresen Primeiro Livro de Poesia (1991), de Alice Vieira Eu bem Vi Nascer o Sol (1994) e de José António Gomes Conto Estrelas em Ti (2000)

\footnotetext{
${ }^{6}$ GOMES, 1991, p. 106.

7 GOMES, 1993, p. 117-121.
} 


\subsection{O teatro}

Com o texto dramático ocorre situação idêntica. Tal como acontece noutros países, não se escrevem muitas peças de teatro para as crianças, e para os jovens não há mesmo nada. Carlos Correia inicia em 1988 uma colecção com 3 peças, que tem por título "Festa Teatral para Escolas Alegres", editada pela Plátano. Porém, António Torrado é manifestamente o autor que mais mérito tem neste domínio. Escreveu e continua a escrever aliciantes peças curtas, produzidas com a intenção de serem representadas pelas crianças nas escolas. São histórias cheias de humor e de exploração de situações burlescas, a par de crítica social. O mesmo comentário aplica-se às peças de Manuel António Pina e Álvaro Magalhães para o Teatro Pé de Vento. Teresa Rita Lopes, Maria Alberta Menéres, Maria Isabel Mendonça Soares, Luísa Ducla Soares, Alice Vieira e José Vaz também têm alguma obra, mas em geral pode dizer-se que o texto dramático era e continua a ser um género pobre, com uma produção realmente escassa.

\subsection{A banda desenhada}

Uma área editorial que tem cada vez mais importância é a banda desenhada. Dantes não havia quase nada escrito por portugueses: tudo, quer os álbuns quer as revistas, eram traduções de material estrangeiro muito mais barato - de origem franco-belga, espanhola ou americana. A editora Asa empenhou-se mais em publicar autores nacionais, com várias colecções históricas ou edições em álbum de contos, tanto da tradição portuguesa como, por exemplo de As Mil e Uma Noites, recontadas por Adolfo Simões Müller e Fernando Bento, e ilustradas principalmente por José Garcês e José Ruy.

\subsection{Contos}

Como já era tradição, continuam a escrever-se muitos contos e histórias pequenas, e disso dão testemunho os comentários dos balanços literários que se produzem todos os anos em Portugal: «Nem só de contos se faz a leitura das crianças... Mas é sempre em contos que mais abunda a produção editorial que lhes é destinada." Acho que não é exagerado afirmar que não há autor para a infância que se preze que não tenha escrito ou recontado contos ou pequenas histórias. 
É de destacar o facto de que não se trata só de contos para leitores principiantes, como também para crianças de 9, 10 anos e mais, que já são capazes de ler textos muito maiores. Outro aspecto observado é a existência, para um público de idade superior a 10 anos, de álbuns de quatro ou cinco contos, livros de capa dura e com letra bastante grande, que dão a impressão de serem para um público mais novo, razão pela qual às vezes perdem o público a quem são destinados. É o caso da importante colecção "Asa Juvenil", que já vem de antes do 25 de Abril.

Outras colecções de contos são: da Livros Horizonte, "Pássaro Livre" e "Pedrinha"; da Plátano, "A Rã Que Ri”, "Caracol", "Livro À Mão" e "Ver e Ler"; da Afrontamento, "Retas e Letras"; da Vega, "Grandes Pequeninos"; da Asa, "Contos de Encantar"; da Desabrochar, "Bem Crescer - Bem Viver" e "Desabrochar Contos". No entanto, na década de 90 manifestou-se um certo recuo do conto ilustrado para esta faixa etária.

Além dos contos originais, assiste-se a uma vaga de recuperação de contos tradicionais de raiz popular - e isso sobretudo nos anos 90 -, recontados por grandes nomes como Alice Vieira e António Torrado. Há a colecção de 14 volumes de "Histórias Tradicionais Portuguesas" escrita por Alice, as adaptações de contos populares com fichas de trabalho para professores que Torrado fez para a editora Civilização, e os 7 volumes de "Contos e Lendas de Macau" em que colaboraram os dois. Uma escritora que ultimamante se tem vindo o manifestar com contos interessantes para a juventude é Ana Saldanha.

\subsection{Narrativas realistas}

No contexto da literatura infanto-juvenil, o termo realismo usa-se em geral para os textos isentos de magia e de poderes sobrenaturais, mas em particular para narrativas com situações radicadas na vida do dia-a-dia. Nelly Novaes Coelho ${ }^{8}$ distingue dentro dessa linha do realismo quotidiano quatro aspectos, baseados no conteúdo, a saber: o realismo crítico, o lúdico, o emotivo e o documental. Como já foi referido, não havia muitas obras deste tipo em Portugal. Ora, esses livros de narrativas em que o texto ganha uma dimensão preferencial em relação às ilustrações e em que os conteúdos são mais elaborados é um dos géneros que vai ganhar projecção nos anos 80 .

Com a publicação, em 1979, de Rosa, minha irmã Rosa, Alice Vieira

${ }^{8}$ COELHO, 1987, p. 109. 
inicia uma carreira em que esse tipo de livro abunda, elevando-o a um nível estético-literário de qualidade, o que não se podia dizer das obras de Saint-Maurice. Nos vinte a cinco anos a seguir, Alice tem publicado quase um livro deste género por ano, sempre do mesmo valor literário. A autora tem uma extrema facilidade em sugerir ambientes bem conhecidos dos jovens de hoje, com personagens normais: já não são as crianças bem-educadas ou as crianças más que finalmente encontram o bom caminho. As personagens dos seus livros lidam com os mesmos problemas que preocupam todos os adolescentes, as mesmas aspirações, os mesmos devaneios, tudo o que caracteriza a juventude. Desta maneira, os leitores aderem à intriga e identificam-se com as personagens.

Os críticos literários costumam gracejar dizendo que depois de Alice Vieira ninguém mais se atreve a escrever tal tipo de livros, com medo de ser sempre comparado com ela. No entanto, há certamente outros autores que conseguem abordar bem a vida dos jovens nos seus vários aspectos. Algumas editoras organizaram estes livros em colecções, de autores diferentes, como fizeram por exemplo a Edinter com "Edinter Jovem", a Verbo com a colecção "Grande Prémio" e a Caminho com "De Par Em Par". Destaca-se o escritor António Mota, com uma produção regular (grande parte na "Edinter Jovem"), tendo a particularidade de tratar da vida e da realidade rural das terras pobres e isoladas do interior de Portugal.

É também dentro do género realista que se situam os romances históricos, que, ao contrário das narrativas de realismo quotidiano, se situam no passado, um passado que em geral é longínquo mas às vezes mais recente, se for ainda experimentado pelo autor. Destas narrativas surgem vários exemplos nos anos 80, escritos por José Jorge Letria, Alberto Oliveira Pinto, Alice Vieira, a dupla Magalhães \& Alçada e outros.

\section{6. "Formula fiction"}

\subsubsection{O fenómeno}

Este termo, que tomo de empréstimo a Maria Nikolajeva, ${ }^{9}$ abrange as narrativas que seguem um padrão repetitivo, ditado por uma moda, como por exemplo os relatos de aventuras, mistérios ou namoros, entre os quais

\footnotetext{
${ }^{9}$ NIKOLAJEVA, 1996, p. 12.
} 
as aventuras são a forma mais popular. São publicadas em colecções que mantêm a mesma estrutura e as mesmas personagens, e correspondem na literatura para adultos a géneros considerados de menor qualidade literária, como romances policiais, e, portanto, são alvo de bastante crítica. No entanto, é consabido que a criança, em certo momento da evolução dos seus hábitos de leitura, prefere este tipo de narrativas. Aparentemente preenchem certa necessidade básica do jovem leitor, a saber, a confirmação da capacidade da leitura. O facto de saber ler sem problemas um verdadeiro livro na sua totalidade enche a criança de alegria e triunfo. Os leitores não esperam realmente aprender algo de novo quando abrem mais um livro de aventuras, mas, como escreve Nikolajeva, "the fascination of formula fiction is based on its predictability, the "joy of recognition" (1996: 12).

Ora, os livros de aventuras e de mistério escritos por autores portugueses, ou melhor, a proliferação deste tipo de literatura, é o fenómeno que logo à partida chama a atenção de quem se debruça, ainda que ligeiramente, sobre a literatura infanto-juvenil portuguesa dos anos 80 . É realmente a grande inovação no panorama literário, e tomou uma envergadura e uma vitalidade que ninguém esperava.

Duas professoras enveredaram por este caminho, Ana Maria Magalhães e Isabel Alçada. Elas ensinavam língua materna e História a crianças lisboetas de 10 a 13 anos, crianças vindas muitas vezes de meios sociais desfavorecidos. Achavam que muitos textos dos manuais escolares não conseguiam captar o interesse dos seus alunos. Assim, com o intento de tornar mais alegres e mais digeríveis as suas aulas de língua portuguesa, começaram a escrever histórias sobre um grupo de amigos, alunos como os seus, que resolvem mistérios. E como não ensinavam só língua mas também História, combinaram episódios da História de Portugal com uma viagem no tempo vivida por dois irmãos. Os alunos gostaram, e elas decidiram publicar as histórias. Assim nasceram duas colecções de livros, primeiro "Uma Aventura", que iria conhecer um êxito enorme entre crianças dos 9 até aos 13, 14 anos, a outra intitulada "Viagens no Tempo".

A colecção "Uma Aventura" parece-se bastante com o tipo de aventuras que se encontram nos livros dos anos 40-50 da escritora inglesa Enid Blyton, tal como aparecem nas colecções "Os Cinco", "Os Sete", etc., de que circulavam muitas traduções em Portugal. Os jovens gostavam bastante deste género de literatura, mas não havia títulos originais de autores portugueses, a não ser algumas obras de Margarida Castel-Branco (colecção “Aconteceu Em...", 1967-1973) e Júlio Gil, obras que ainda pecavam pelos 
defeitos da literatura moralista.

Ora, os livros de Magalhães \& Alçada é que, logo de início, conseguiram mobilizar o gosto dos jovens, não só porque seguiram a matriz criada por Blyton, garantia de êxito (grupo de amigos acompanhados por um cão a viverem aventuras espantosas), como ainda porque a colecção reflecte a natural adesão dos jovens ao espírito coleccionador. E sobretudo porque em vez de sítios, situações e tradições britânicos, as autoras se inspiraram num espaço e em personagens portuguesas, tentando ligar o leitor a ambientes conhecíveis ou acessíveis. E decerto parte do sucesso da colecção reside no facto de as narrativas ocorrerem em terra portuguesa. Desta forma os leitores aderiram ainda mais a este tipo de narrativa que já de si fascina tanto os jovens.

A fórmula de um grupo de amigos que vive aventuras espantosas em Portugal produziu tanto efeito que a receita foi rapidamente experimentada por outras editoras, que encarregaram autores de escreverem histórias parecidas. Assim, novas colecções vão surgindo e ocupando o seu espaço próprio ano após ano, mas a crescente vitalidade é, segundo José António Gomes, ${ }^{10}$ mais visível no número de títulos publicados e nas elevadas tiragens do que na capacidade de renovação formal e de conteúdo. Ele lamenta a tentativa de penetração neste mercado por parte de diversas editoras atraídas pela febre do lucro. Algumas delas tinham até então dado poucas provas no campo do livro infantil e juvenil de autores portugueses.

\subsubsection{Colecções portuguesas}

Até 2000 surgiram umas 22 colecções de que apresento aqui as mais interessantes, por ordem cronológica de publicação.

1) Uma Aventura, de Ana Maria Magalhães \& Isabel Alçada (1982 - Caminho)

Esta colecção, que conta 47 volumes escritos em 33 anos, teve quase de imediato um imenso êxito e resultou num verdadeiro fenómeno social: a maioria das crianças entre 9 e 13 anos devora os livros todos dessa colecção, lê-os de uma ponta à outra. Daí lhe vem o seu grande mérito, a saber, o de ter posto a ler toda uma geração de crianças. As narrativas contam as peripécias de duas gémeas, três rapazes e dois cães, acolitados, como é usual, por alguns companheiros de ocasião, que se metem em aventura após aventura. Como

${ }^{10}$ GOMES, 1991, p.108. 
já referi, a grande diferença com "Os Cinco" ou "Os Sete" de Enid Blyton é que tudo se situa quase sempre em Portugal, o que aumenta enormemente a possibilidade de identificação e de familiarização com o texto.

A aventura ou o mistério a desvendar têm invariavelmente a ver com um aspecto histórico, artístico ou geográfico de Portugal, quer porque se trata de um objeto de arte perdido ou roubado quer porque o sítio é um castelo, um palácio ou uma igreja existentes. As autoras querem valorizar vários aspectos do património geral português.

As autoras assinalam igualmente que com esta colecção houve também a preocupação de adequar as histórias à realidade das crianças de hoje. Assim, a família agora é diferente do que era há vinte anos, quando era constituída sempre pelo pai, mãe e filhos. Hoje em dia as crianças podem ter um padrasto ou uma madrasta, as avós já não são aquelas senhoras muito velhinhas de carrapito e óculos redondinhos, são mulheres ainda plenas de actividade, que fazem desporto, que têm a sua vida profissional, que ainda têm namorados, etc. As raparigas ja não querem parecer rapazes para poder entrar nas aventuras, porque isso deixou de fazer sentido.

As duas professoras tinham uma consciência muito nítida das palavras que prendem e das que fazem tropeçar os leitores dessas idades. Assim, um dos seus mecanismos é privilegiar as frases curtas e os diálogos vivos, em detrimento das descrições alongadas. O estilo é simples e fluente. Os diálogos são escritos numa linguagem corrente, muito perto da oralidade actual dos jovens, coisa que eles apreciam muito, porque estabelece uma relação de cumplicidade. Desta maneira, as autoras conseguem entrar no mundo da fantasia, do imaginário e do sonho, sem contudo, deixar de ensinar, de apresentar situações históricas, que de outro modo se tornariam menos interessantes para um público tão exigente. Já se fez uma série de filmes a partir das histórias.

As ilustrações, abundantes, são em todos os volumes da autoria do artista Arlindo Fagundes, que também ilustra as outras colecções da dupla de escritoras.

2) Viagens no Tempo, de Ana Maria Magalhães \& Isabel Alçada (1985 Caminho)

Como o título deixa adivinhar, nessa colecção a componente histórica é muito vincada, sendo uma colecção de romances históricos de aventuras. Os 15 volumes têm uma tiragem bastante alta, embora não tanto como os da 
colecção anterior, provavelmente por se tratar de narrativas mais difíceis, e na maioria também mais extensas. O público-alvo é também um pouco mais velho, dos 12-13 em diante. As histórias situam-se sempre no passado de Portugal, a que dois irmãos e um cientista se deslocam com uma máquina do tempo.

Os livros constam de duas partes: a narrativa propriamente dita e uma nota explicativa. Na primeira, a informação histórica é doseada, como que polvilhando a história, sendo inserida num fio condutor que é sempre uma história particular de alguém. As autoras acham que a História sem pessoas é desprovida de graça e perde a realidade. Por isso, os protagonistas travam amizades com toda a laia de gente, cobrindo assim a sociedade em todas as facetas, mas encontram de vez em quando também figuras históricas verdadeiras. São livros com um enredo interessante e bem estruturado, capazes de despertar o maior interesse pela História de Portugal, de clarificar ideias e aprofundar conhecimentos. Pessoalmente lamento que a imagem que se dá no que respeita aos papéis sexuais seja altamente estereotipada. ${ }^{11}$

A nota explicativa tem uma marcada preocupação pela vertente informativa. Ocupa só 10 páginas no primeiro volume, mas vai aumentando em cada volume, chegando a 100 páginas em Brasil! Brasil!. Essa parte explicativa, de que é muito difícil avaliar o impacto, não é lida por inteiro pelas crianças, funciona como complemento e para responder de antemão a questões que os leitores põem às autoras.

3) Asa Delta, de Ana Maria Magalhães \& Isabel Alçada (1987 - Caminho)

Essa colecção só consta de três volumes cujo entrecho gira em redor de um aspecto artístico de Portugal: os tapetes de Arraiolos, os azulejos e a cerâmica de Barcelos. O leitor, acompanhando o desenrolar da aventura, é confrontado com "temas, técnicas e aspectos históricos da arte popular portuguesa, adquirindo assim, quase sem dar por isso, conhecimentos vários sobre a sua gente e o seu país» (contracapa). Esta colecção não teve o êxito das outras, o que é de estranhar, porque as personagens e o enredo são mais bem elaborados do que na colecção "Uma Aventura".

4) 1001 Detectives, de Carlos Correia, Maria Alberta Menéres e Natércia Rocha (1987 - Caminho)

${ }^{11}$ Analisei este assunto em BLOCKEEL, 1995. 
Estes 16 (até 1993) romances de aventuras detectivescas foram escritos em conjunto e neles actuam dois irmãos, filhos de um casal de feirantes, que viajam com a mercadoria por Portugal, envolvendo-se assim por todo o país em pequenas aventuras e mistérios, que os detectives, sobretudo o rapaz, inteligente mas vaidoso, solucionam. Embora os mistérios não tenham nada a ver com o país, salienta-se o ambiente português. Os mistérios são às vezes inteligentemente urdidos, e às vezes muito rebuscados, parecendo até artificiais, tornando as aventuras pouco perigosas ou interessantes. Os autores valorizam o raciocínio em vez da utilização da pura força física, o que é meritório.

5) Triângulo Jota, de Álvaro Magalhães (1989 - Asa)

Álvaro Magalhães tem na editora Asa uma colecção de aventuras chamada "Triângulo Jota", actualmente com 18 títulos, que constitui a melhor série portuguesa de "thrillers" juvenis em livro. Nela, a caracterização das personagens é bem elaborada, as aventuras são cativantes, o enredo está sempre bem urdido, de maneira a deixar espaço para suspense até ao fim do livro. Por isso são livros que se lêem de um só fôlego. Além disso, a linguagem é cuidada, fluida e próxima da linguagem dos jovens. À diferença de "Uma Aventura", o enredo não envolve um mistério que seja especificamente português, mas as aventuras desenvolvem-se sempre no território de Portugal. O desfecho da aventura é muito menos previsível do que em "Uma Aventura", o que permite uma maior adesão por parte do leitor, fazendo da colecção uma das mais lidas pelos jovens. Para isso contribuem também o tom humorístico, a abordagem sincera das preocupações afectivas e sexuais da adolescência e a ausência de qualquer infantilidade. O autor nomeia as coisas da vida real sem rodeios, mas também sem vulgaridade alguma, deixando lugar ao humor e ao jogo, sendo assim um dos poucos escritores que sente o que preocupa os jovens leitores, que os respeita na sua qualidade de seres que procuram e querem saber mais do mundo adulto, um autor que antecipa a curiosidade dos adolescentes e que sabe maravilhosamente colher o leitor de improviso. É de notar que nos últimos volumes da série o autor transita do género policial para o fantástico. Merecem particular destaque as sugestivas ilustrações, de José Pedro Costa, que, altamente influenciadas pela $\mathrm{BD}$, contribuem para o merecido êxito da colecção.

6) O Clube das Chaves, de Maria Teresa Maia Gonzalez \& Maria do Rosário Pedreira (1990 - Verbo) 
Na primeira da 21 histórias um rapaz recebe como herança do avô uma caixa cheia de chaves com mensagens em código que levarão às respectivas fechaduras. Com a irmã, a prima e um amigo vai desvendando livro após livro mistério após mistério. Não ocorrem grandes aventuras perigosas, trata-se antes da procura, em museus ou bibliotecas em vários sítios do país, de elementos do mundo histórico ou artístico português para resolver as mensagens enigmáticas do avô. Ao mesmo tempo segue-se o dia-a-dia das três famílias lisboetas em que eles vivem, com problemas de divórcio, atribulações de adolescentes, etc. As situações familiares são observadas com conhecimento e analisadas com um objectivo pedagógico. Desta maneira as autoras conseguem juntar elementos didácticos e informativos com ensinamentos morais. Mas, a intencionalidade moral e pedagógica se sobrepõe sempre às preocupações literárias. E, de facto, é literatura de mensagem, de valores bastante conservadores - as meninas são muito "fadas do lar" e os rapazes muito homens -, que, em vez de dar às crianças instrumentos para tirarem as suas próprias conclusões, ensina demasiado. Como o texto é inutilmente sobrecarregado de informações, muitos dos diálogos são bastante fastidiosos, impedindo que o enredo seja verdadeiramente dinâmico: as narrativas arrastam-se.

7) Labirinto, de Ana Teresa Pereira (1991 - Caminho)

Os 5 volumes dessa colecção, escritos entre 1991 e 1992, são narrativas de aventuras situadas todas no arquipélago da Madeira. São bastante curtas e caracterizadas por um estilo cuidado e despojado, que só oferece o necessário, mas têm um enredo bem estruturado, sem ladrões convencionais, escrito numa linguagem fluida, ensinando, sem que se note muito e sem nenhum didactismo, várias coisas interessantes sobre estas ilhas portuguesas. Os protagonistas são jovens bem equilibrados que têm um interesse saudável pelo mundo que os rodeia, que descobrem ao desvendar os segredos das casas quase fantásticas onde passam uns dias de férias. Original e fenómeno pouco frequente é o interesse pelo mundo dos livros, que se manifesta através da figura da mãe, que é uma escritora policial empedernida que se esquece de tudo enquanto escreve.

8) A Chave dos Mundos, de Gabriela Morais (e Fátima Domingues para os números 1, 2 e 3) (1991 - Dom Quixote)

É a única colecção em que as aventuras empolgantes se passam num tempo ou num sítio que não têm nada a ver com Portugal. O palco das 
aventuras ora é a Grécia Antiga, ora o mundo da demanda do Graal pelos cavaleiros da Távola Redonda, ora o Iraque, ora o mundo de Mozart. Essas aventuras, impregnadas de acção, sabem manter o suspense até ao final. Além de bem escritos, são livros que abrem o horizonte do leitor para um conhecimento de culturas universais, facto que só com pouca frequência acontece na literatura infanto-juvenil portuguesa.

9) Vamos Viajar, de Ana Saldanha (1995 - Campo das Letras)

Nesta colecção de 5 volumes uns jovens fazem viagens escolares dentro (Trás-os-Montes) ou fora do país (Inglaterra, França, Espanha, Irlanda), num intento de dar a conhecer o dia-a-dia de jovens europeus.

10) Profissão: Adolescente, de Maria Teresa Maia Gonzalez (1996 - Difel)

É uma colecção destinada a leitores dos 14 aos 18 anos que, contrariamente às outras, tem sempre jovens diferentes como protagonistas. Espanta o seu ritmo de produção, com 14 volumes publicados em quatro anos. Estes tratam todo o leque de problemas com que possam lidar os adolescentes: fazer dieta, ter borbulhas, ser diabético, viver a separação dos pais, ter uma mãe alcoólica ou um pai que está preso, etc. A autora ventila uma crítica mordaz à sociedade que não se ajusta à criança ou ao jovem, onde há uma falta de verdadeiro afecto entre pais e filhos, o que, em vários casos, leva ao drama ou à morte. Tal como na colecção que escreve em parceria com Maria do Rosário Pedreira, "O Clube das Chaves", a abordagem dos problemas contemporâneos tem sempre um acentuado e exagerado cunho moralizante. No entanto, apesar da qualidade literária bastante fraca e do vincado tom moralizador das mensagens, estes livros são bastante bem aceites pelos jovens.

\section{A temática}

Como o subcapítulo anterior deixa claro, os temas abordados na produção pós-revolucionária não se limitam a mistérios e aventuras emocionantes; surgem livros que tratam o dia-a-dia dos adolescentes através de uma multiplicidade de temas, vários deles até então tabus, e que são tratados sobretudo nos romances dirigidos aos pré-adolescentes e aos adolescentes, o novo público-alvo.

Nos países da Europa Ocidental e do Norte, a literatura infanto-juvenil, 
na esteira de Maio de 1968, evoluiu para um aguçado sentido de realismo, o que foi acompanhado de uma ampliação de temas. A sociedade tinha mudado naqueles países, o que mais marcadamente se podia ver na estrutura familiar. A literatura infanto-juvenil não ficou para trás, antes acompanhou essa mudança, abordando com a imprescindível serenidade problemas como as sequelas das guerras, a fome, o desemprego e outros. No panorama português não tinha acontecido nada desse género, o que era lógico, uma vez que no plano sociológico o regime salazarista não quis mudanças, e se as havia, como a emigração e a guerra colonial, eram temas de que não era permitido falar. Com a restauração da democracia em Portugal, era óbvio que os temas tratados nos livros também evoluíssem, ou, como diz José António Gomes no seu ensaio Para uma História da Literatura Portuguesa para a Infância e a Juventude:" "Escrever para crianças e jovens em clima de liberdade implicou, naturalmente, uma aproximação gradual a temas que se encontravam arredados da produção literária ou eram tratados de modo menos directo." Gomes deu-se ao trabalho de procurar para cada novo tema pelo menos dois ou três livros que o tratam de maneira aprofundada. Os livros que menciona são na maioria prosa de ficção para todas as idades, embora para alguns temas não esqueça a poesia e o teatro. Vou limitar-me aqui a uma síntese dos temas que ele encontrou na literatura infanto-juvenil.

O tema mais importante não é senão a própria adolescência nos seus mais variados aspectos: as interacções entre amigos e entre irmãos, a entrada difícil na adolescência, a entrada no mundo do trabalho, tanto para rapazes como para raparigas, o desabrochar da sexualidade, o confronto com a solidão e a realidade da morte, a vivência escolar e a droga. Em segundo lugar vem a família com os seus possíveis conflitos, a interacção entre as gerações, o divórcio e as famílias mono-parentais, o abandono afectivo, a infância na província, a vida dos núcleos familiares de origem camponesa e os problemas da velhice.

A sociedade é outro tema fulcral abordado nos romances, em que se pode encontrar facetas tão variadas como a denúncia das desigualdades sociais, a pobreza, a sociedade de consumo, as migrações das províncias para as grandes urbes, a emigração, a técnica na era dos computadores, o racismo, o multiculturalismo, a preservação ambiental, o desporto e o ante e o pós-Revolução. É óbvio que metade destes temas apareceram desde

12 GOMES, 1998, p.45. 
sempre na literatura para jovens, mas a mudança está na maneira como são tratados. Antes foram abordados só de forma subreptícia ou capciosa, já que a existência da censura não dava condições para que os escritores tratassem de tais assuntos com plena liberdade de expressão.

Como disse, as relações familiares são abordadas noutra perspectiva: a perspectiva do adolescente que quer ir à procura de si e do mundo e que neste caminho se confronta com as barreiras que a família lhe pode às vezes impor. Neste domínio sobressai o nome de Alice Vieira, a escritora que mais se aproxima das tendências crítico-realistas que caracterizam a literatura de países nórdicos. Alice é o primeiro autor a tratar não só a sociedade actual tal como se apresentou depois do 25 de Abril, este mundo que estava a mudar tanto e a tão incrível velocidade, como também o núcleo familiar, igualmente objecto de muitas mudanças. Trata nos seus livros assuntos e problemas de família que todas as crianças normais têm uma ou outra vez na vida, e consegue fazer isso com muito à-vontade, espontaneidade e justeza. Diz que «é o adulto que há [nela] que recorda sem mitificações a infância que passou", o que quer dizer que está consciente de que as coisas não são tão boas como os adultos se lembram, porque crescer é um processo doloroso: "a infância raramente é o paraíso que nós, adultos, dizemos que foì. A autora não transmite nem uma visão negra da vida nem uma visão cor-de-rosa, mas transmite a ideia de que, se os jovens quiserem, podem ultrapassar e melhorar a realidade. Falando dos assuntos que, embora sendo duros, são reais, tenta fazer pensar e reagir os jovens. Por isso recusa-se a pés juntos a tratar de modo moralista esses problemas, não cai na armadilha de tratar os problemas de maneira demasiado dramática, pelo contrário, integra os problemas sociais de maneira inteiramente natural na narrativa. Aquilo que ela pretende é fazer dos seus leitores jovens interessados. Fazer com que eles, depois da leitura dos seus livros, se interessem por saber mais, por conhecer como o mundo funciona, por aprender.

Outros autores que tratam essa temática são, entre outros, Álvaro Magalhães, Alexandre Honrado e Maria Teresa Maia Gonzalez, mas esta última leva a abordagem dos problemas contemporâneos ao exagero, parecendo-se as suas narrativas bastante com os livros de aflições e miséria dos anos 70 nos países nórdicos.Na realidade, a maioria dos autores escreve mais abertamente sobre esses aspectos da sociedade do que se fazia antes (exceptuando-se,

13 GUINCHO, 1998. 
no entanto, sobre as temáticas sexuais), mas poucos testemunham o surpreendente à-vontade e a serenidade de uma Alice Vieira.

Contudo, ao lado desta ampliação temática não se esgotaram os veios de antes de 1974, bem pelo contrário, continuam a ser escritas obras de carácter histórico e apologético, se não com o mesmo moralismo e conservadorismo de outrora, muitas vezes ainda com certa intenção didáctica. O interesse renovado pela própria história manifesta-se claramente no facto de quase todas as grandes editoras para crianças terem uma ou duas colecções sobre a História, seja com objectivo didáctico seja meramente de ficção. Esse novo olhar sobre o passado não é próprio da literatura juvenil, uma vez que se verifica também na literatura para adultos: "portraying the nation's history at its peak or in decline, intertwining its ancient heroic and mythical themes [...], it must be recognized that historical novels have had a dominant position in recent fiction". ${ }^{13}$

Como se explica esse interesse? As autoras Magalhães \& Alçada avançaram uma opinião interessante (entrevista de 27 de Junho de 1995). Aparentemente, o problema radica no Estado Novo, em que a História era explicada como uma História apenas de santos, heróis e mártires, todos pensados numa visão moral, na grandeza do país, na beleza da luta pelo país, dando lugar a uma infantilização da História. Nas escolas tinha de se saber tudo de cor, nomes e datas e batalhas, as coisas de grande importância e as de pouca importância. Era um ensino enciclopédico, pensado para criar uma memória colectiva única, que se identificou apenas com as épocas mais gloriosas da história portuguesa. Salazar propôs aos portugueses serem orgulhosos dela.

Ora, aconteceu que com a revolução de 1974 e o fim do Império os portugueses sentiram em geral uma certa vergonha pelo seu passado de colonizador-opressor. Por parte dos governos da esquerda houve uma tentativa para deslocar essa imagem fascista da realidade nacional presente e passada. Isso resultou num verdadeiro descuido do elemento nacionalista, porque a esquerda não costuma reivindicar os valores de pátria e sentimento nacional pelo seu teor afectivo, de cariz irracional. Mas este sentimento de vergonha não durou muito tempo, depressa se voltou a falar do passado glorioso do país. Constata-se uma renovada procura de traços de identidade colectiva, dos sinais e lugares da memória e, simultaneamente a este questionar da identidade cultural e das suas imagens, retoma-se o culto das grandes personalidades históricas.

Em todo o caso, é um facto que a História portuguesa se tornou tema e/ou pano de fundo em muitos livros, a saber, em quase 15\% da produção 
portuguesa de romances juvenis. Para começar há, pois, a já referida colecção histórica "Viagens no Tempo", de Magalhães \& Alçada, que abrange a quase totalidade da História portuguesa. Para a mesma faixa etária, publicou-se na Edinter a colecção "Contos da História". Os sete volumes foram escritos por encomenda nos anos 1991-1992 por vários autores, nomeadamente José Jorge Letria, Alexandre Honrado, Natércia Rocha, Gabriela Morais, Alberto Oliveira Pinto, Henriqueta Török e Fátima Domingues. Os livros pretendem contar a História de Portugal em forma de romance, começando ainda antes da existência como nação com a época de Viriato, até ao início da segunda dinastia portuguesa.

A colecção "À Descoberta com Gil e Inês" (Caminho, 9 volumes 1992 - 2000), de Glória Bastos, pretende iniciar crianças dos 7 aos 10 anos ao Portugal Quinhentista. A informação histórica é articulada com actividades lúdicas porque é "brincando, imaginando, "vivendo", que se despertará o gosto e interesse pelo passado, pela nossa História". Para a colecção "A Minha Memória" da Asa, Margarida Brandão colaborou com memórias de Vasco da Gama e do Infante D. Henrique, e recriou também as viagens dos navegadores portugueses em volumes avulsos. Fora dessas colecções, ainda há outros livros que focalizam a História de Portugal, como alguns romances de Margarida Castel-Branco, Luísa Dacosta, José Jorge Letria e Alice Vieira.

Não podemos deixar de referir o campo do livro informativo, onde também existe o fenómeno das colecções que tratam de despertar um maior interesse pela História de Portugal, nem o campo da Banda Desenhada. Para dizer a verdade, é extremamente difícil encontrar entre os livros de BD escritos ou desenhados por portugueses um livro que não tenha um tema histórico ou que não esteja ligado à literatura portuguesa (lendas, contos e mitos). Pode-se dizer que, sobretudo até finais da década de 80, se há BD portuguesa, é em 90\% dos casos BD sobre um aspecto de Portugal. A editora Asa parece destacar-se nesse campo, com uma trintena de álbuns.

Convém acrescentar aqui mais três aspectos. O primeiro é que muitos livros juvenis não históricos têm um enredo que se desenvolve em redor de um pormenor da História ou da cultura portuguesas, e que em muitos livros cujo enredo não diz de modo algum respeito à História portuguesa há frequentemente um bom momento para introduzi-la. Observações que dão especial relevo à História gloriosa de Portugal, são realmente muito frequentes na literatura juvenil.

Outro elemento é o facto que quase todas as narrativas históricas 
tratam da história de Portugal e não do resto do mundo, sendo Gabriela Morais uma das poucas pessoas que se aventura amiúde na história alheia "(na colecção "A Chave do Mundo"). O terceiro aspecto que achamos importante salientar é que, além das novas publicações, foram reeditados vários livros de antes de 1974 que tratam da História de Portugal ou que são aventuras juvenis situadas dentro da História. Os pais actuais conhecem estes livros da sua própria infância e muitos têm tendência a comprá-los para os filhos.

Mas não é apenas a história nacional que é contemplada na literatura juvenil, também surgem outros temas intimamente ligados a Portugal. Ao lado da colecção "Asa Delta", que focaliza o património artístico de Portugal, a dupla Magalhães \& Alçada também escreveu um livro de arte, intitulado Histórias dos Jerónimos. A escritora e professora de arte Castel-Branco conta em Histórias da História da Arte em Portugal (Asa 1990) uma aventura de dois irmãos através da cultura portuguesa. Na área da geografia, Adolfo Simões Müller escreveu dois livros sobre os rios portugueses e para o campo da literatura adaptou obras de Júlio Dinis, tal como fez Teresa Bernardino para A Peregrinação. Como já referi, a temática da literatura portuguesa observa-se fortemente na banda desenhada.

De tudo o que acima foi exposto depreende-se que a literatura juvenil portuguesa tem, pois, muitíssimas obras de cariz histórico-cultural. ${ }^{14}$

\section{Resumindo}

Constata-se que a abordagem de duas faixas etárias antes esquecidas pelos escritores portugueses, a saber a dos pré-adolescentes e a dos adolescentes e "young adults", levou a uma muito marcada ampliação nos géneros praticados. Os géneros que estiveram sempre presentes no mercado, e isso é sobretudo o caso do conto, não perderam o fôlego, pelo contrário, ganharam em qualidade, uma vez que a censura constrangedora desaparecera. Refira-se que dois géneros quase não têm expressão na literatura portuguesa, a ficção científica e o fantástico, feição que a literatura para adultos, exceptuando algumas obras de autores modernos, também

${ }^{14}$ Investiguei como se aborda essa temática e em que medida constitui um fenómeno característico de Portugal in: BLOCKEEL, 2001. 
apresenta. No domínio do fantástico para jovens, a excepção à regra é Manuel António Pina.

A grande novidade do período pós-revolucionário, contudo, vem de dois géneros antes quase ignorados pelos escritores portugueses, o romance realista para jovens e a "formula fiction", que no espaço de 20 anos se conseguiu desenvolver e elevar a alturas nunca antes atingidas em Portugal. O primeiro tipo de livros não é nada típico, existe por todo o lado, mas com a escritora Alice Vieira alcançou-se pela primeira vez um nível estético-literário nunca atingido no mundo da literatura juvenil portuguesa. Com a sua escrita conseguiu pôr Portugal a par das literaturas estrangeiras; são prova disso as várias traduções que a sua obra conheceu e o facto de que por pouco não ganhou o prestigioso prémio Hans Christian Andersen em 1996 e 1998.

No que respeita ao segundo género, a "formula fiction", Portugal conheceu um fenómeno que nem todos os países conhecem. Se se tratasse de simples aventuras atípicas, cujo interesse reside apenas no enredo e na acção, podia dizer-se que se inserem na tradição da Europa Ocidental que caracterizou o período entre as duas Guerras Mundiais, com escritores como Enid Blyton. Tratar-se-ia de um verdadeiro atraso português. Mas acontece que se está aqui perante um modelo com características típicas, um modelo que apresenta dois níveis. Há por um lado o nível do mistério a desvendar, da genuína aventura e pura acção, e por outro lado há também um nível informativo. De facto, as referências a obras de arte, museus, monumentos, locais portugueses, a actualidade, etc., tornam-se a peça central da trama narrativa, à volta da qual se gera o mistério. Esse esbater das fronteiras entre a ficção e a não-ficção é característica da escrita moderna e contemporânea, como explica Margaret Meek: "In modern writing for children this absolute distinction [between fiction and non-fiction] is no longer sustainable. Both novels and "fact" books deal with the same subjects in a wide range of styles and presentations". ${ }^{15}$

Contudo, se Ana Maria Magalhães \& Isabel Alçada, as responsáveis do modelo, conseguem uma equilibrada articulação do lúdico e do didáctico, tornando os temas culturais e históricos apetecíveis, isso nem sempre acontece nas outras colecções, encontrando-se apenas em "Triângulo Jota" de Álvaro Magalhães o mesmo à-vontade e qualidade de escrita. Além disso, o facto de várias colecções imitarem recursos e técnicas

15 MEEK, 1996. p.4. 
narrativas utilizadas por Magalhães \& Alçada como, por exemplo, os protagonistas gémeos, aumenta sensivelmente o risco de se petrificar que o género corre.

No que diz respeito ao conteúdo das narrativas, é óbvio que os jovens requerem outra temática que não contos infantis ou adaptações quaisquer. Trata-se de lhes oferecer romances e narrativas intencionalmente a eles destinados, textos que retratassem a sua própria realidade, em que as personagens se defrontassem com os mesmos problemas que os leitores. Assim, a partir de 1974, aborda-se a temática do dia-a-dia dos jovens finalmente duma maneira mais aberta e natural, com uma crítica do tecido social e das fraquezas humanas. Ao lado desta temática os escritores portugueses não se esqueceram de tratar o património histórico-cultural português sob todos os ângulos. A forte presença da história e da cultura portuguesas, ligada à ausência de outras culturas, é uma das características marcantes da literatura juvenil do fim do século XX, que faz que ainda difira das outras literaturas europeias. Mas apesar disso, é um facto que o período pós-revolucionário foi crucial na valorização da produção literária para os jovens e que esta se está a alinhar pelo caminho europeu. Não é de admirar, pois, que a literatura juvenil portuguesa adquirisse o estatuto de literatura de verdade.

\section{Referências Bibliográficas}

BLOCKEEL, Francesca. Mulheres no Romance Histórico Infanto-juvenil Português dos Anos 80. In: O Rosto Feminino da Expansão Portuguesa. Actas do Congresso Internacional da Comissão para a Igualdade e para os Direitos das Mulheres (21-25/11/1994), Lisboa: Cadernos "Condição Feminina" n. 43, v. II, p. 667-682, 1995.

BLOCKEEL, Francesca. Literatura Juvenil Portuguesa Contemporânea: Identidade e Alteridade. Lisboa: Caminho, Coleccção Universitária, 2001.

COELHO, Nelly Novaes. Literatura infantil. História-Teoria-Análise. 4. ed. revista. São Paulo: Edições Quiron Ltda, 1987.

GOMES, José António. Literatura para a infância e a juventude. Balanço literário de 1990. Vértice 38. p.105-109, Maio de 1991.

GOMES, José António. A Poesia na literatura para a infância. A produção portuguesa, do pós-guerra à actualidade e o caso de Matilde Rosa Araújo. 
Porto: Asa, Colecção "Perspectivas Actuais", 1993.

GOMES, José António. Para uma História da Literatura Portuguesa para a Infância e a Juventude. Lisboa: Instituto Português do Livro e das Bibliotecas, 1998.

GUINCHO, Maria dos Anjos Maurício. History and fiction in João Aguiar's The Voice of the Gods. In: Memory, History and Critique: European Identity at the Millenium. Proceedings of the Fifth Conference of the International Society for the Study of European Ideas, 19-24/8/1996, Utrecht: CD-rom ISSEI, 1998.

KNOWLES, Murray; MALMKJÆR, Kirsten. Language and Control in Children's Literature. London: Routledge, 1996.

MEEK, Margaret. "Introduction" to the International Companion. Encyclopedia of Children's Literature. Edited by Peter Hunt, London and New York: Routledge, 1996.

NIKOLAJEVA, Maria. Introduction to the Theory of Children's Literature. Tallinn: Tallinn Pedagogical University, p.1-13, 1996.

PINTO-CORREIA, João David. A literatura juvenil em Portugal. Lisboa: Ministério da Educação Nacional, 'Exposição de livros infantis', 15-31 de Outubro de 1973.

ROCHA, Natércia. Breve História da Literatura para Crianças em Portugal. Lisboa: Instituto de Cultura e Língua Portuguesa, "Biblioteca Breve" v. 97, 1984.

\section{Resumo}

Este artigo é um apanhado da evolução e das importantes mudanças que conheceu a literatura juvenil portuguesa depois da Revolução dos Cravos (1974), abordado a partir de três pontos de vista: o público-alvo, os géneros e a temática.

\section{Abstract}

In this essay we study the evolution and the important changes of contemporary juvenile literature in Portugal after the Revolution of the Carnations (1974) from three points of view: readers, genres and themes. 